\title{
Parental Awareness of the Potential Health Implications of Stem Cells Found in the Pediatric Dentition
}

\section{Aristotle Lyssikatos ${ }^{1}$}

\section{ABSTRACT}

Objective: This study explored the parental awareness of the importance of the potential health benefits of harvesting stem cells located in the pulp chambers of the pediatric dentition.

Methods: The study population comprised of 107 mothers of pediatric patients seeking dental treatment at a health center in New Jersey. The mothers of the pediatric patients completed a questionnaire assessing their knowledge about stem cells in the pediatric dentition.

Results: $104(97.2 \%)$ of the 107 mothers that completed the questionnaire had no knowledge about stem cells. The three study subjects that did have insight about stem cells learned about stem cells from either the television or the internet and no study subjects learned about stem cells from neither dental providers nor pediatricians.

Conclusion: Our results suggest that health care providers need to not only treat patient symptoms but educate patients about the potential health benefits of harvesting stem cells from extracted/exfoliated pediatric teeth. Further analytical research is called for.

Keywords: Stem cells, Cryopreservation, Public health, Primary dentition

'DDS, MS, FAGD

\section{Contact Author}

Dr. Aristotle Lyssikatos ajl255@nyu.edu

J Oral Health Comm Dent 2012;6(1)1-3

\section{INTRODUCTION}

Stem cell research has been on the cutting edge of medical technology for the past decade (1). A tremendous amount of research, funding, and resources from both the public and private sector have paved the way to assist clinicians in combating numerous diseases utilizing stem cells (2). This topic is so vital to the future of public health that stem cell research has had a profound impact on clinicians, patients, legislators and even the president of the United States of America has had to rule on behalf of stem cell research (3). To date, diseases and ailments such as juvenile diabetes, heart disease, various cancers including leukemia and lymphoma, and vision loss have been treated utilizing stem cell therapy (4-7).

More recently it has been discovered that dental tissue, specifically the dental pulp chamber, is a new source of stem cells that can be harvested and cryopreserved $(8,17)$. Further research has revealed that the stem cells of primary teeth are mesenchymal in origin, which is the same cellular origin for neuronal and bone tissue $(9,10,11,14)$. For this reason, scientists hypothesized that stem cells from the primary dentition can combat diseases of the hard tissue (bone, cartilage, and dentition) and the nervous system of a patient $(12,15,16)$. Unfortunately, a lack of insight and education about this potential life saving stem cell research has allowed for millions of viable primary teeth to be discarded rather than cryopreserved for future applications (13). Dentists, pediatricians, and other public health specialists are on the front line of this healthcare issue and need to inform their patients and help them understand the issue and need for retaining these primary teeth. The aim of this study was to 
determine the extent of knowledge that parents of pediatric patients possess regarding stem cells located in the primary dentition and the potential life-saving attributes of the stem cells.

\section{MATERIAL AND METHODS}

This study was conducted at a not for profit health center located in the state of New Jersey, United States of America.

\section{Subjects}

The study population consisted of females who were raising their own children between the ages of 6 to 12. These females consistently came to the health center for dental care and were asked to fill out the corresponding questionnaire. The typical female patient of the health center is an immigrant from South America with a large contingency from Ecuador and Peru. These females tend to live below the poverty line and many are unemployed, unmarried and do not receive financial assistance from their former spouses. All the respondents received financial assistance for health care services which is typical of people earning near or less than the poverty line. A total of 107 subjects were randomly asked and completed the questionnaire. All subjects that were asked to complete the questionnaire did so (no subjects refused) and all questionnaires were entirely filled out. The study was conducted over a two month period beginning on July 14, 2010 and finishing on September 14, 2010.

\section{Questionnaire instrument}

The questionnaire was developed by the author and consisted of four questions. The questions were written in both English and Spanish using laymen's terms in order to ensure full comprehension. Subjects were told if they did not understand a question to please ask the author to clarify the question. Clarification was needed a total of four times for the participants.

The initial question was do you have a child who is between the ages of 6 to 12 ? Question number two was have you ever been informed that baby teeth contain stem cells that could potentially be utilized for future health needs?

If the participant answered yes, the following question (question number three) was to be answered, how were you informed that baby teeth contain stem cells? A list was available with the following choices as possible check offs, dentist, medical physician, internet, television, radio, friend, and other (with a line left for a write in answer). If the participant answered "no" to question number two, the following question (question number four) was to be answered, how many times has your child seen a dentist in their lifetime?
Table 1: Number of participants informed that the primary dentition contains stem cells that could potentially be utilized for future health eeds

\begin{tabular}{lcccc} 
Participants & \#never informed & \#informed & \%never informed \%informed \\
\hline 107 & 104 & 3 & 97.2 & 2.8
\end{tabular}

\section{Analysis}

The questionnaire data were manually entered using Microsoft Excel 2000 (Microsoft, Redmond,WA, USA).

\section{RESULTS}

Of the 107 participants that were asked to fill out the questionnaire, none refused and all questionnaires were entirely filled out, resulting in a $100 \%$ response rate.

Table 1 describes the response to question number two, with an overall 97.2\% (104 respondents) stating that they have never been informed that the primary dentition contains stem cells that could potentially be utilized for future health needs.

Table 2 describes how the three participants that were informed that the primary dentition contains stem cells became informed of the fact. One participant (33.3\%) stated she discovered this information from the internet, while the other two participants $(66.7 \%)$ stated they were made aware about the discovery on the television news.

Table 3 shows the response to question number four, the amount of visits each child has had to a dentist in their lifetime. The distribution ranged from a single visit up to 12 visits, the mean number of visits per child was 8.9.

Table 4 shows the amount of visits each child had to a dentist as a percentage of the overall 107 participants.

\section{DISCUSSION AND CONCLUSION}

This study shows that as medical technology advances clinicians need to stay current

Table 2: How the participants became informed that the primary dentition contained stem cells

\begin{tabular}{|lccccccc|}
\hline Participans & Internet & Radio & Television & Dentist & Physician & Friend & Other \\
\hline 3 & 1 & 0 & 2 & 0 & 0 & 0 & 0
\end{tabular}

Table 3: Amount of visits each child has had to a dentist in their lifetime

$\begin{array}{llllllllllll}\text { \# Visits } & 1 & 2 & 3 & 4 & 5 & 6 & 7 & 8 & 9 & 10 & 11 \\ \text { \# Participants } & 7 & 9 & 7 & 8 & 10 & 16 & 19 & 12 & 8 & 4 & 3 \\ \end{array}$

Table 4: Percentage of visits each child has had to a dentist in their lifetime from the 107 total participants

\begin{tabular}{|c|c|c|c|c|c|c|c|c|c|c|c|}
\hline \# Visits & 1 & 2 & 3 & 4 & 5 & 6 & 7 & 8 & 9 & 10 & 11 \\
\hline$\%$ & 6.5 & 8.4 & 6.5 & 7.4 & 9.3 & 15.0 & 17.8 & 11.2 & 7.5 & 3.7 & 2.8 \\
\hline
\end{tabular}


with clinical research in order to administer the best healthcare possible (19). The findings of our study revealed, that patients are not aware of the potential health benefits of retaining extracted primary teeth. Even in the present day's mass communication and available resources this new advancement in dental science has not been well introduced to the population.

As evidenced by the results, patients of the pediatric age group are being treated by dentists, pediatricians, and primary care physicians and are not being informed of the benefits of saving extracted primary teeth. Medical professionals need to better educate and inform patients of the potential health benefit of retaining and cryopreserving the primary dentition. Parents and guardians of patients within this age group should be given educational literature (in multiple languages) and the contact information of the companies that store these teeth (18).

It can be assumed that stem cell research in oral healthcare may change the standard of practice for dentists. Rather than discarding extracted primary teeth in either a sharps container (for teeth that do not contain amalgam) or in a scrap amalgam canister (for teeth that do contain amalgam) the dental community must develop a protocol for delivering these teeth to storage in a viable setting (20). Stem cell research in oral healthcare demands that clinicians, governing agencies, and patients re-evaluate their interpretation of "baby teeth" to a potential life saving entity. For the entrepreneur, this new science may lead to a marketable industry, following in the footsteps of viacord and cord blood registry.

Further analytical research needs to be conducted with respect to the knowledge that dentists have on this stem cell subject. It would not be a surprise if a high percentage of dentists had no insight about stem cells in primary teeth or the clinical research being conducted on the stem cells. If this assumption is correct, the dental academic centers need to make our current and future dental providers aware of this developing science.

\section{ACKNOWLEDGEMENTS}

The author is grateful to Despina Dallas DDS, FAGD, and Stelios Viazis PhD for their assistance in study preparation, and to the voluntary cooperation of the parents at the health center.

\section{REFERENCES}

1. Stem Cell Basics. In Stem Cell Information [World Wide Web site]. Bethesda, MD: National Institutes of Health, U.S. Department of Health and Human Services, 2009.

2. Research Funding. In Stem Cell Information [World Wide Web site]. Bethesda, MD: National Institutes of Health, U.S. Department of Health and Human Services, 2006.

3. Congressional Legislation. In Stem Cell Information [World Wide Web site]. Bethesda, MD: National Institutes of Health, US Department of Health and Human Services, 2009.

4. Haller MJ, Viener HL, Brusko $T$, et al. Insulin Requirements, $\mathrm{HbA} 1 \mathrm{c}$, and Stimulated C-peptide following Autologous Umbilical Cord Blood Transfusion in Children with T1D. Abstract presented at: Annual Meeting of the American Diabetes Association, Scientific Sessions; June 22-26, 2007 Chicago, IL.

5. Harris DT, He X, Ahmad N, et al. The potential of cord blood stem cells for tissue engineering. Poster presented at: International Society for Stem Cell Research. June 2005; San Francisco, CA. Sunkomat, JNE, S Goldman, DT Harris and MA Gaballa. Cord bloodderived MNCs delivered intracoronary contribute differently to vascularization compared to CD34+ cells in the rat model of acute ischemia. Submitted, Stem Cells, 2006. Harris, DT, H He and M Gaballa. The potential of cord blood stem cells for use in regenerative medicine of the heart. 2nd International Stem Cells Meeting, San Francisco, CA, 22-24 Jan 2007.

6. Shibata A, Harris DT, Billings PR. Concentrations of estrogens and IGFs in umbilical cord blood plasma: A comparison among Caucasian, Hispanic, and Asian-American Females. J Clin Endocrinol Metab 2002;87(2):810-15.

7. Harris DT, He X, Ahmad N, et al. The potential of cord blood stem cells for tissue engineering. Poster presented at: International Society for Stem Cell Research. June 2005; San Francisco, CA Harris, DT, X. He, M. Badowski and JC Nichols. Regenerative Medicine of the Eye: A Short Review. In Press, Regen. Med. May 2006 Harris DT, He X, Badowski $\mathrm{M}$, Nicols JC. Regenerative Medicine of the Eye: A Short Review. Stem Cell Repair \& Regeneration, Vol. 3, Levicar N, Habib NA, Dimarakis I, Gordon MY (Ed.s), Imperial College Press (2007), In press.

8. Petrovic V, Stefanovic V. Dental tissue- new source for stem cells. Scientific World Journal 2009;9:1167-77.

9. Yan X, Qin H, Qu C, Tuan RS, Shi S, Huang GT. IPS cells reprogrammed from mesenchymal-like stem/progenitor cells of dental tissue origin. Stem Cells Dev 2009.

10. Karaoz E, Dogan BN, Aksoy A, Gacar G, Akyuz $S$, Ayhan $S$, et al. Isolation and in vitro characterization of dental pulp stem cells from natal teeth. Histochem Cell Biol 2009.

11. Huang AH, Chen YK, Lin LM, Shieh TY, Chan AW. Isolation and characterization of dental pulp stems cells from a supernumerary tooth. J Oral Pathol Med. 2008;37(9):571-74.

12. Arthur A, Shi S, Zannettino AC, Fujii N, Gronthos S, Koblar SA. Implanted adult human dental pulp stem cells induce endogenous axon guidance. Stem Cells 2009;27(9):2229-37.

13. Arora V, Arora P, Munshi AK. Banking stem cells from human exfoliated deciduous teeth (SHED) saving for the future. J Clin Pediatr Dent 2009;33(4):289-94.

14. Koyama N, Okubo Y, Nakao K, Bessho $\mathrm{K}$. Evaluation of pluripotency in human dental pulp cells. J Oral Maxillofac Surg 2009;67(3):501-06.

15. Huang GT, Gronthos S, Shi S. Mesenchymal stem cells derived from dental tissues vs. those from other sources: their biology and role in regenerative medicine. J Dent Res 2009;88(9):792-806.

16. Yalvac ME, Ramazanoglu M, Rizvanov AA, Sahin F, Bayrak OF, Salli U, et al. Isolation and characterization of stem cells derived from human third molar tooth germs of young adults: implications in neo-vascularization, osteo-, adipo- and neurogenesis. Pharmacogenomics $J$ 2009.

17. Spath L, Rotilio V, Alessandrini M, Gambara G, De Angelis L, Mancini M, Mitsiadis TA, Vivarelli E, Naro F, Filippini A, Papaccio G. Explant-derived human dental pulp stem cells enhance differentiation and proliferation potentials. J Cell Mol Med 2009.

18. Woods EJ, Perry BC, Hockema JJ, Larson L, Zhou D, Goebel WS. Optimized cryopreservation method for human dental pulp-derived stem cells and their tissues of origin for banking and clinical use. Cryobiology 2009.

19. D'aquino R, De Rosa A, Laino G, Caruso F, Guida L, Rullo R, et al. Human dental pulp stem cells: from biology to clinical applications. J Exp Zool (Mol Dev Evol) 2008;310B:1-8.

20. Perry BC, Zhou D, Wu X, Yang FC, Byers $\mathrm{MA}$, Chu TM, et al. Collection, cryopreservation, and characterization of human dental pulp-derived mesenchymal stem cells for banking and clinical use. Tissue Eng Part C Methods 2008; 14(2):149-56. 